\title{
The involvement of HPV in cervical oncogenesis
}

\author{
Mihai Mitran ${ }^{1 *}$, Carmen Georgescu', Sorin Puia', Loredana Mitran², Alexandra Bruja' \\ From The 9th Edition of the Scientific Days of the National Institute for Infectious Diseases Prof Dr Matei Bals \\ Bucharest, Romania. 23-25 October 2013
}

\section{Background}

The site of action of HPV in the cervix is the squamous junction cylinder and the transformation zone. Abnormal epidermoid metaplasia and basal hyperplasia is the starting point for epithelial atypia.

\section{Methods}

We assessed the dysplastic lesions of the cervix which underwent extended biopsy in the past 3 years - 579 cases and herpes virus type 2 infection was present in 2 cases.

\section{Results}

HPV-HR (high-risk) was positive in 377 cases, HPV-LR (low-risk) was positive in 165 cases and in 35 cases no HPV typing was performed. The herpes virus type 2 infection was present in 2 cases.

Cytology showed LSIL (low grade squamous intraepithelial lesion) in 329 cases and HSIL (high grade squamous intraepithelial lesion) in 189 cases.

Histological examination revealed cervical intraepithelial neoplasia (CIN) I in 69 cases and CIN II, CIN III in 183 cases and carcinoma in situ in 6 cases.

HSIL cases all presented infection with $\operatorname{HR}(16,18,31)$ strains.

\section{Conclusion}

Concomitance of cervical dysplasia with HSIL cytology is a major risk factor in cervical neoplasia.

\section{Authors' details}

'Clinical Hospital of Obstetrics and Gynecology "Prof. Dr. Panait Sârbu", Bucharest, Romania. ${ }^{2}$ Elias University Emergency Hospital, Bucharest, Romania.

Published: 16 December 2013

\footnotetext{
*Correspondence: michael_digital@yahoo.com

"Clinical Hospital of Obstetrics and Gynecology "Prof. Dr. Panait Sârbu", Bucharest, Romania

Full list of author information is available at the end of the article
}

doi:10.1186/1471-2334-13-S1-037

Cite this article as: Mitran et al:: The involvement of HPV in cervical

oncogenesis. BMC Infectious Diseases 2013 13(Suppl 1):O37.
Submit your next manuscript to BioMed Central and take full advantage of:

- Convenient online submission

- Thorough peer review

- No space constraints or color figure charges

- Immediate publication on acceptance

- Inclusion in PubMed, CAS, Scopus and Google Scholar

- Research which is freely available for redistribution

Submit your manuscript at www.biomedcentral.com/submit
() Biomed Central 